DOI: $10.1515 /$ pts-2017-0036

PHYSICAL AND TECHNICAL ENERGY PROBLEMS

\title{
DEVELOPMENT AND COMPARISON OF TECHNICAL SOLUTIONS FOR ELECTRICITY MONITORING EQUIPMENT
}

\author{
A. Potapovs, A. Obushevs \\ Smart Grid Research Centre \\ Institute of Physical Energetics \\ 11 Krivu Street, Riga, LV-1006, LATVIA
}

\begin{abstract}
The paper focuses on the elaboration of a demand-side management platform for optimal energy management strategies; the topicality is related to the description and comparison of the developed electricity monitoring and control equipment. The article describes two versions based on Atmega328 and STM32 microcontrollers, a lower and higher level of precision, and other distinct performance parameters. At the end of the article, the results of the testing of the two types of equipment are given and their comparison is made.
\end{abstract}

Keywords: demand side management, demand response, Internet of Things, monitoring, sockets, voltage measurement

\section{INTRODUCTION}

The trend to strengthen consumers' flexibility in the e-market environment is conditioned by a wider expansion of Smart Grid Technologies, including Intelligent Metering Systems. Prospectively, bulk installations of Smart Meters alongside with the development of more flexible appliances should lead to the widespread public acceptance and deployment of price-responsive demand [1], [2].

To achieve a high level of reliability and robustness in power systems, the grid is designed for peak demand rather than the average load. This can result in underutilised power generation and distribution systems and a waste of natural resources. Moreover, most of the fast responding generators that are used to meet the peak load, such as gas and coal units, are expensive and have large carbon footprints. To overcome these problems, different programs have been proposed to shape users' energy consumption profiles. Such programs allow the available generation capacity to be employed more efficiently so that a new generation and transmission infrastructure does not have to be installed. These programs, generally known as demand-side management (DSM), aim either at reducing consumption or shifting consumption.

Most of the current load control decisions in existing DSM systems are made manually, which makes it difficult for the participants to monitor the real-time prices 
and use other advanced pricing methods. In fact, a lack of knowledge among end users about how to respond to time-varying prices is currently the main barrier for fully utilising the benefits of real-time pricing methods and DSM, in general. This problem can be resolved by equipping users with home automation systems and by implementing automated energy consumption scheduling units that can draw on pricing information to schedule the operation of various residential appliances on behalf of customers [3].

The present research aims to compare two different schematic solutions for power monitoring and control equipment in order to choose the most efficient one by comparing parameters such as electricity consumption, current and voltage measurement accuracy, samples per second, price and potential for future improvements.

\section{HOME AREA NETWORK MONITORING \& CONTROL}

The Demand Side Management-Smart Home Lab of the Smart Grid Research Centre (presented in Fig. 1) is equipped with the developed monitoring \& control socket hardware (Fig. 2) for the elaboration of a DSM platform based on the open source solution proposed in the OpenEnergyMonitor project [4] with the following features: sending data at periodic intervals to a web-connected base-station; realtime monitoring of active, reactive, apparent powers, currents, voltage and extra sensors (temperature, humidity, etc.); remote control possibility (switch off/on socket devices); easily customised for a variety of applications.

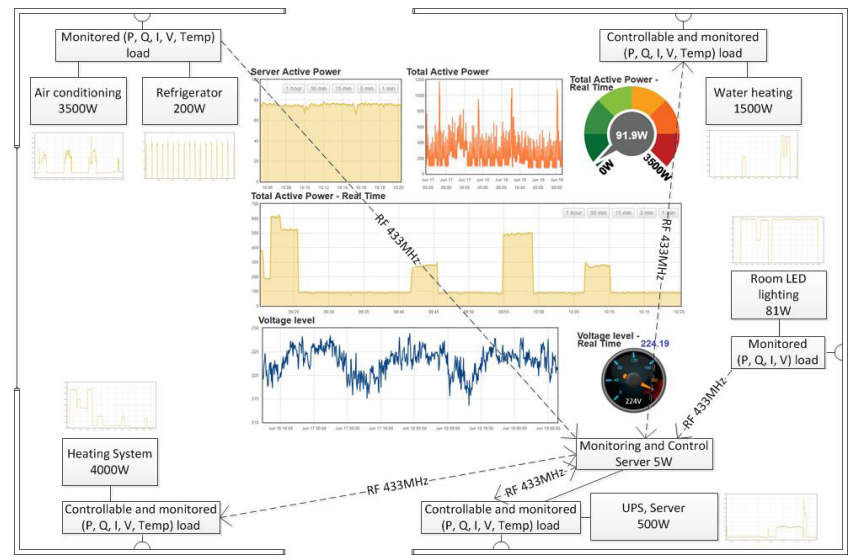

Fig. 1. Home area network facility with real-time monitoring \& control.

\section{MONITORING \& CONTROL HARDWARE DESIGN}

\section{A. First Version of Real-Time Energy Monitoring and Control System}

The first version of the device, described in more detail in [4], [5], operates on the basis of 8-bit Atmega 328 microcontroller (Fig. 2). A network transformer with two secondary windings is used to power the plates and measure network voltages, while the current transformer is used to measure the load current. An electromag- 
netic relay is used to control the load. To transmit data using the radio network, the radio module RFM12B is used, operating in the $433 \mathrm{MHz}$ band.

On the basis of the experimental operation of the device, the following characteristic shortcomings have been discovered in the device scheme:

a. Analogue signals are read out using the 10-bit ADC built-in Atmega328 microcontroller, which allows reading network voltage/current with $3.22 \cdot 10^{-3} \mathrm{~V}$ step, automatically providing low voltage and current measurement accuracy;

b. Under actual operating conditions, the performance of Atmega 328 microcontroller ADC is also characterised by a low sampling frequency equal to $35 \mathrm{kSPS}$ (samples per second) in case of using one ADC and $7.5 \mathrm{kSPS}$ using two ADC conversions, which makes it difficult to accurately detect zero point, and also reduces the accuracy of current and voltage measurement at various pulsed loads;

c. A network voltage transformer is used to read the network voltage, which is characterised by a specific nonlinearity, and its secondary winding voltage changes its value depending on the total load of the transformer (the relay operates or not, the radio is transmitting or not, etc.);

d. The design is not compact enough to be used comfortably as a smart socket.

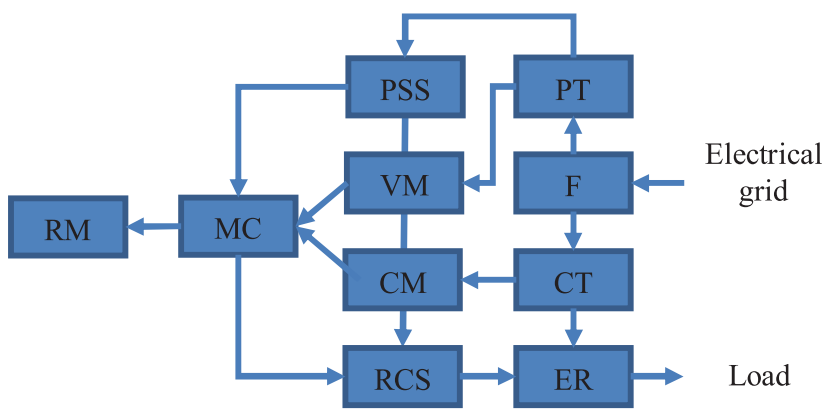

Fig. 2. Old version of socket monitoring \& control hardware.

The first version of the device contains the following components: $\mathrm{MC}-$ 8-bit microcontroller Atmega 328; PT - dual secondary winding power transformer $230 \mathrm{~V}$ to 2 x 6V; CT - linear current transformer 1500:1, 15A; VMS - voltage meter scheme; CMS - current meter scheme; PSS - 3.3V power source scheme; RM - radio module RFM12B; RCS - relay control scheme; R - electromagnetic relay $230 \mathrm{~V}$, $16 \mathrm{~A} ; \mathrm{F}$ - fuse 16A.

\section{B. Second Version of Real-Time Energy Monitoring and Control System}

After defining shortcomings of the first version, a new electricity monitoring and control scheme has been developed (Fig. 3). The new version of the device is based on the 32-bit microcontroller STM32. The current measurement is carried out using a current sensor, but the voltage measurement is performed without a galvanic reference using only the voltage divider and the midpoint of the artificial supply 
voltage. For the provision of radio communications, the system contains the RFM$69 \mathrm{HW}$ radio module, which provides stable indoor communication with the central control point in the indoor environment, within meters and more. The load control board, like its first version, is equipped with a 16A electromagnetic relay. Component feed plate contains $3 \mathrm{~W}$ AC-DC pulse power supply with $3.3 \mathrm{~V}$ DC output voltage.

Analogue signals are read out using the 16 bit ADC built-in STM32 microcontroller, which allows reading network voltage/current with $5 \cdot 10^{-5} \mathrm{~V}$ step, automatically providing high voltage and current measurement accuracy. The performance of microcontroller ADC is also characterised by a high sampling frequency equal to $135 \mathrm{kSPS}$ for one ADC and 30kSPS for two ADC conversion, which makes it more accurately detect zero points, and also increase the accuracy of current and voltage measurement at various pulsed loads.

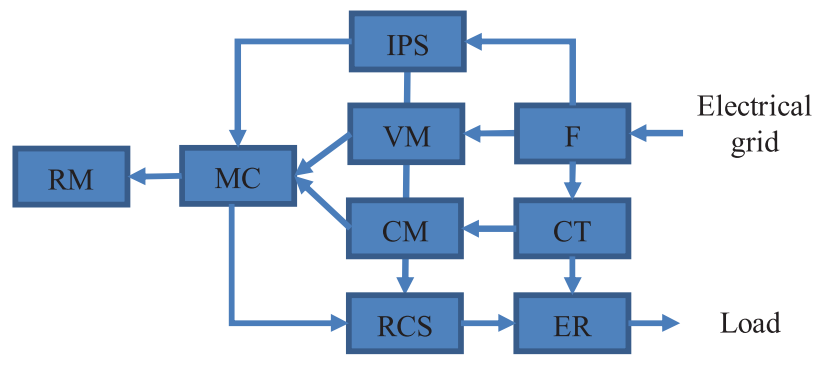

Fig. 3. New version of socket monitoring \& control hardware.

The second version of the device contains the following components: $\mathrm{MC}$ - 32-bit microcontroller STM32; IPS - impulse power supply $230 \mathrm{~V}$ to $3.3 \mathrm{~V}$; CT linear current transformer 1500:1, 15A; VMS - voltage meter scheme; CMS - current meter scheme; RM - radio module RFM69HW; RCS - relay control scheme; $\mathrm{R}$ - electromagnetic relay $230 \mathrm{~V}, 16 \mathrm{~A} ; \mathrm{F}$ - fuse $16 \mathrm{~A}$, varistor $270 \mathrm{~V}$.

\section{MATHEMATICAL MODEL OF ELECTRICAL PARAMETER MEASUREMENT}

Root mean square (RMS) voltage and current values determine the operation of the electrical system (the electric heater generates heat in direct dependence on the RMS values of the voltage and current of the network). To sample a number of values over the network voltage period, it is necessary to sum the squares of the sample points, divide by the number of points per period (when determining the number of sample points, the Nyquist-Shannon sampling theorem is taken into account), and make the square root of the obtained result.

In a real network, at near zero voltage, there can be both "zero shelves" and repeated transitions through zero voltage, which will significantly introduce an error in the measurement. To overcome this issue, voltage tolerance zones are introduced (introducing the boundary of the zero-crossing voltage from the positive and negative sides), usually $0.05 \mathrm{~V}$ in both directions, and also the frequency insensitivity zones (limiting the permissible frequency of the voltage signal). 
Using the digitized data from the 16-bit ADC derived from delta-sigma on the built-in microcontroller, voltage and current root mean square values are calculated based on their average quadratic values during 10 periods.

\section{RESULTS AND DISCUSSION}

Preliminary test results with technology comparison are presented in Table 1 and Fig. 4, where second equipment generation demonstrates significant improvements in price, computation speed and memory.

Table 1

Comparison between the First and Second Versions

\begin{tabular}{|l|c|c|}
\hline & I & II \\
\hline Flash, Kbytes & ATMEGA328 & STM32 \\
\hline SRAM, Kbytes & 32 & 256 \\
\hline CPU, MHz & 2 & 32 \\
\hline ADC speed, kSPS & 20 & 72 \\
\hline Equipment consumption, W & $9.6-50$ & $125-1000$ \\
\hline SPS at 10 cycle period & 0.83 & 0.42 \\
\hline MAE, V & 5720 & 26800 \\
\hline RMSE, V & 0.1921 & 0.1455 \\
\hline MAX Error, V & 0.2458 & 0.1759 \\
\hline Price, EUR $€$ & 0.6415 & 0.4130 \\
\hline
\end{tabular}

To compare voltage measurements, PMU (Phasor Measurement Unit) has been used and assumed as a voltage reference with high precision. Voltage errors are still significant from the voltage regulation point of view, and the primary field of precision improvement is the implementation of more advanced mathematical techniques such as FFT (Fast Fourier Transform) algorithms. However, from the perspective of energy regulation (demand response based on energy price signals), these errors are sufficient.

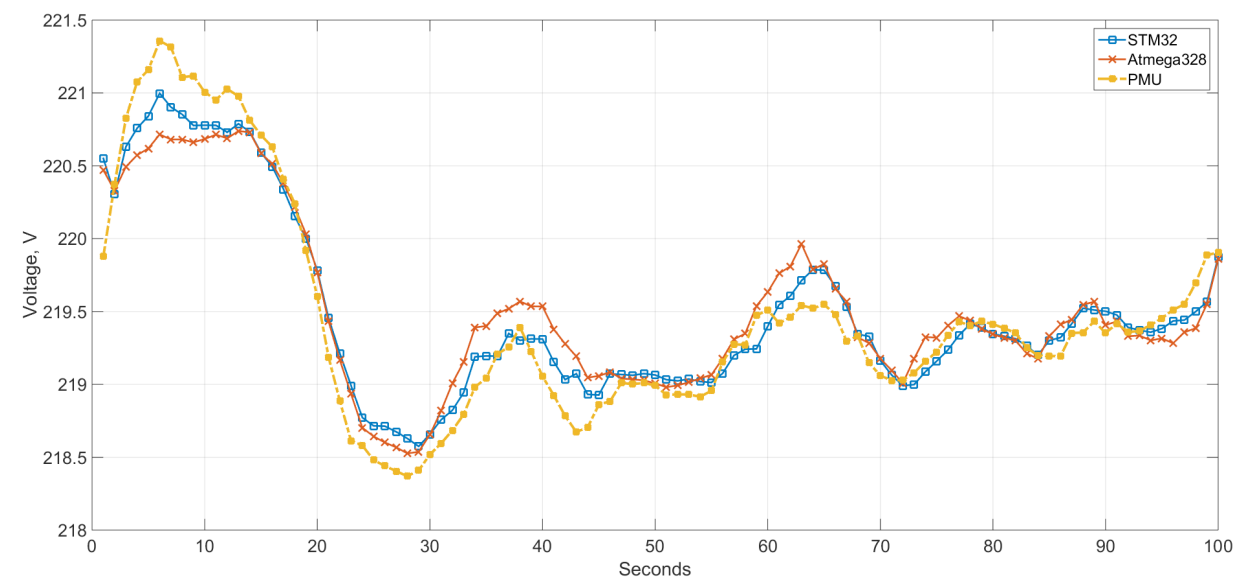

Fig. 4. Comparison between voltage measurements. 


\section{CONCLUSIONS AND FURTHER RESEARCH}

A smart metering system has been developed to support the development of a new metering infrastructure, which could be the first step for network management system integration. The present research has been dedicated to the development and comparison of two inexpensive technical solutions (smart sockets) for electricity monitoring with sufficient precision and control possibilities. Experimental operation of the first device has demonstrated inherent shortcomings, which have been solved with a more advanced second generation device (faster, cheaper and precise).

Implementation of more advanced mathematics can provide accuracy improvement deriving parameters (V, I, P, Q) and bring an opportunity to obtain new observables such as frequency and harmonics.

\section{ACKNOWLEDGEMENTS}

The research has been supported by ERA-Net Smart Grids Plus project CLOUDGRID No. 77547 (Transnational CLOUD for Interconnection of Demonstration Facilities for Smart GRID Lab Research \& Development), with support from the European Unions Horizon 2020 research and innovation programme.

\section{REFERENCES}

1. Turcik, M., Oleinikova, I., \& Kolcun, M. (2011). End-users'energy management strategies in market environment. Presentation at the International Scientific Symposium Elektroenergetika, 21-23 September 2011, High Tatras, Slovakia.

2. Oleinikova, I., Mutule, A., Obushevs, A., \& Antoskovs, N. (2016). Smart grid development: Multinational demo project analysis. Latvian Journal of Physics and Technical Sciences, 6, ISSN 0868-8257 DOI: 10.1515/lpts-2016-0038

3. Samadi, P., Mohsenian-Rad, H., Wong, V. W. S., \& Schober, R. (2015). The role of demand side management. IEEE Smart Grid Newsletter Compendium, 37-38.

4. Open Energy Monitor. (n.d.). Available at http://openenergymonitor.org/

5. Obushevs, A., Oleinikova, I., Mutule, A., \& Potapovs, A. Demand side management platform for HAN flexibility estimation. In Proceedings of the 56th Annual International Scientific Conference of Riga Technical University, Section "Power and Electrical Engineering”, 14 October 2015, Riga, Latvia. ISBN 978-1-4673-9752-0. 


\author{
A.Potapovs, A. Obuševs \\ Kopsavilkums
}

\begin{abstract}
Dotais raksts veltīts pieprasījuma vadības platformas izstrādei optimālās elektroenerǵijas pārvaldības stratēgijiai, pievēršot galveno uzmanību izstrādātās elektroenerǵijas uzraudzības un kontroles iekārtu aprakstam un salīdzināšanā. Rakstā aprakstītas divas versijas, kuru pamatā ir Atmega328 un STM32 mikrokontrolleri ar augstāko un zemāko precizitāti, kā arī citi atškirīgi veiktspējas parametri. Nobeigumā doti detalizēti abu piedāvājamo iekārtu testēšanas rezultāti, veikts to salīdzinājums, kā arī izteikti secinājumi par tiem.
\end{abstract}

03.11.2017. 